Article

\title{
Evolution of Black Talc upon Thermal Treatment
}

\author{
Yuhang Meng ${ }^{1}$, Weimin Xie ${ }^{1}$, Haiyan $\mathrm{Wu}^{2,3,4}$, Sarwar Muhammad Tariq ${ }^{2,3,4} \mathbb{D}$ and Huaming Yang $1,2,3,4, *(\mathbb{D}$ \\ 1 Hunan Key Laboratory of Mineral Materials and Application, School of Minerals Processing and \\ Bioengineering, Central South University, Changsha 410083, China; myhzsy@csu.edu.cn (Y.M.); \\ weiminxie@csu.edu.cn (W.X.) \\ 2 Engineering Research Center of Nano-Geomaterials of Ministry of Education, China University of \\ Geosciences, Wuhan 430074, China; haiyanwu@cug.edu.cn (H.W.); tariqsarwar@cug.edu.cn (S.M.T.) \\ 3 Faculty of Materials Science and Chemistry, China University of Geosciences, Wuhan 430074, China \\ 4 Key Laboratory of Functional Geomaterials in China Nonmetallic Minerals Industry, China University of \\ Geosciences, Wuhan 430074, China \\ * Correspondence: hmyang@csu.edu.cn; Tel.: +86-731-8883-0549; Fax: +86-731-8871-0804
}

check for

updates

Citation: Meng, Y.; Xie, W.; Wu, H.; Tariq, S.M.; Yang, H. Evolution of Black Talc upon Thermal Treatment. Minerals 2022, 12, 155. https:// doi.org/10.3390/min12020155

Academic Editor: Rossella Arletti

Received: 4 January 2022

Accepted: 24 January 2022

Published: 27 January 2022

Publisher's Note: MDPI stays neutral with regard to jurisdictional claims in published maps and institutional affiliations.

Copyright: (c) 2022 by the authors. Licensee MDPI, Basel, Switzerland. This article is an open access article distributed under the terms and conditions of the Creative Commons Attribution (CC BY) license (https:/ / creativecommons.org/licenses/by/ $4.0 /)$.

\begin{abstract}
Black talc is a natural silicate clay mineral with a typical 2:1 layered structure, low electrical conductivity, large specific surface area, and high thermal stability. The world's largest black talc mine, with known reserves of one billion tons, is located in China's Jiangxi province. Due to the restriction of its color, the application of black talc is only limited to ceramic raw materials, coating filler, waterproof materials, and other low-end application industries. Thermal treatment is a common method of clay mineral modification. It is vital to examine the structural and physical changes of black talc during calcination in order to prepare black-talc-based composites and to broaden their applications. This work discusses the evolution of black talc upon thermal treatment $\left(30-1000^{\circ} \mathrm{C}\right)$ and the corresponding structural changes. The thermal stability of minerals was analyzed via thermogravimetric (TG) analysis and thermogravimetry-mass spectrometry (TG-MS). The decomposition of minerals during calcination consists of four processes: dehydration, organic carbon decomposition, dihydroxylation, and phase transformation. In situ FTIR and in situ XRD were employed to track changes in black talc in real time during thermal treatment. At $800{ }^{\circ} \mathrm{C}$, black talc was found to begin to go through dihydroxylation, and the crystallinity index decreased significantly. The XRD pattern of samples at $950{ }^{\circ} \mathrm{C}$ (T950) showed the reflection of the enstatite structure, and the relative crystallinity index was $27.3 \%$, indicating that the mineral had undergone phase transformation. In addition, the BrunauerEmmet-Teller (BET), laser particle size analyzer, Zeta potential, scanning electron microscopy (SEM), and transmission electron microscopy (TEM) techniques were used to systematically characterize the physicochemical properties of minerals at different temperatures. The results show that black talc's particle size and specific surface area increase with the calcination temperature. The surface charge changes, and more amorphous $\mathrm{SiO}_{2}$ and $\mathrm{MgO}$ appear, indicating that thermal treatment could induce structural changes and activate the surface of black talc.
\end{abstract}

Keywords: black talc; thermal evolution; crystallographic structure; physicochemical aspects; activated surface

\section{Introduction}

Clay minerals are abundant in nature, constituting approximately half of the lithosphere and worn crust. Clay minerals have diverse morphologies, such as nanosheet [1], nanotube [2], nano-rod [3], and many more. They are mainly composed of silicon, oxygen, aluminum, magnesium, and other elements, and their particle size is less than $0.01 \mathrm{~mm}[4,5]$. Clay minerals such as halloysite [6-8], montmorillonite [9,10], diatomite [11], kaolinite [12], talc [13], and palygorskite [14] have garnered significant attention in recent years for their potential use in nanocomposite synthesis [15-17]. For example, in kaolinite intercalation compounds, novel drug delivery systems (DDSs) have been successfully synthesized by 
introducing organic guest species with different chain lengths between layers of lamellar kaolinite [18]. Composites with a tunable antibacterial activity were successfully obtained by loading $\mathrm{Fe}_{2} \mathrm{O}_{3}$ nanoparticles on the surface of modified kaolinite nanosheets [19]. Halloysite nanotubes surface grafted with distearoyl phosphoethanolamine can be used to load the antitumor drug paclitaxel (PTX), achieving a loading capacity of $18.44 \%$ and drug release which is close to $100 \%$ [20].

Talc is a hydroxylated, magnesium-rich, layered silicate that consists of $\mathrm{SiO}_{4}$ tetrahedral sheets and $\mathrm{MgO}_{4}(\mathrm{OH})_{2}$ octahedral sheets in a 2:1 ratio [21,22]. Talc, a natural layered clay mineral with good thermal stability, hydrophobicity, and adsorption properties, has been used in numerous applications [23,24]. Black talc is a unique talc, containing organic carbon between layers which makes it darker than pure talc. China has the world's largest black talc mine, located in Guangfeng County, Jiangxi Province, with proven reserves of more than 1 billion tons [25]. Due to its high thermal stability and high whiteness after calcination, black talc is mainly fired for producing ceramics [26,27]. Nevertheless, the use of clay minerals in functional composites is becoming more and more common, and clay minerals are emerging as a highly significant strategic resource for the world's economies [28-30]. Due to the limitation of black talc's color and single processing mode, however, the main application of black talc at the present stage is limited only to traditional firing or firing of ceramics and to other low-end industries. In addition, calcination is a common processing method of talc, but the structure and property changes that talc undergoes during heat treatment are not clear, which seriously limits the application of its calcined products in composite materials. Therefore, a systematic study of the morphology, surface properties, and crystal structure of black talc is of great theoretical significance to realize the functional design of black talc. At the same time, the study of its crystal chemical and material properties is helpful to discover the unique material properties of black talc and guide the material application and processing technology of black talc to achieve the goal of improving the industrial application value of black talc.

Using black talc in functional composites requires an understanding of the structure and characteristics of black talc during calcination at different temperatures. This study investigates the thermal stability of black talc using the thermogravimetry/differential scanning calorimetry (TG/DSC) and thermogravimetry-mass spectrometry (TG-MS) techniques, and tracks the structural changes of black talc in real time during thermal treatment via in situ X-ray diffraction (XRD) and in situ Fourier transform infrared spectrometry (FTIR). Furthermore, the physicochemical properties of minerals at different temperatures were systematically characterized using the Brunauer-Emmet-Teller (BET), laser particle size analyzer, Zeta potential, scanning electron microscopy (SEM), and transmission electron microscopy (TEM) techniques, with the goal of providing a theoretical foundation for studying calcined black talc in composite materials.

\section{Materials and Methods}

\subsection{Materials}

This work addresses original black talc minerals obtained from Guangfeng County (Jiangxi Province, China), containing talc and a small number of impurities (including quartz, dolomite, and organic carbon). Table 1 shows the chemical composition of the samples according to the oxides analyzed via XRF.

Table 1. Chemical composition of pristine black talc (mass fraction, $\%$ ).

\begin{tabular}{cccccccc}
\hline Component & $\mathrm{SiO}_{\mathbf{2}}$ & $\mathbf{M g O}$ & $\mathrm{CaO}$ & $\mathbf{F}$ & $\mathbf{P}_{\mathbf{2}} \mathbf{O}_{5}$ & $\mathbf{A l}_{2} \mathbf{O}_{3}$ & $\mathbf{N a}_{2} \mathbf{O}$ \\
wt $\%$ & 65.03 & 30.669 & 2.716 & 0.697 & 0.235 & 0.175 & 0.156 \\
Component & $\mathrm{Fe}_{\mathbf{2}} \mathbf{O}_{3}$ & $\mathbf{S O}_{3}$ & $\mathbf{Z n O}$ & $\mathbf{K}_{\mathbf{2}} \mathbf{O}$ & $\mathbf{M n O}$ & $\mathrm{TiO}_{2}$ & \\
wt\% & 0.150 & 0.068 & 0.038 & 0.025 & 0.022 & 0.020 & \\
\hline
\end{tabular}




\subsection{Experiments}

\subsubsection{Thermal Treatment}

Calcined black talc samples were obtained via continuous heating of original black talc, labeled as T100, T200, T300, T400, T500, T550, T600, T650, T700, T750, T800, T850, T900, T950, and T1000 (representing the target temperatures of 100, 200, 300, 400, 500, 550, 600, $650,700,750,800,850,900,950$, and $1000^{\circ} \mathrm{C}$ ). A laboratory-programmable muffle furnace was used to calcine black talc, in which the program was set to start from $30{ }^{\circ} \mathrm{C}$ (Talc), the heating rate was $10^{\circ} \mathrm{C} / \mathrm{min}$, and each sample was kept at its target temperature for $120 \mathrm{~min}$. When the muffle furnace temperature dropped to room temperature, the calcined black talc was taken out to study the effect of the calcination temperature.

\subsubsection{Quantitative Analysis of Amorphous $\mathrm{SiO}_{2}$ and $\mathrm{MgO}$ Contents}

After thermal treatment, the crystal structure of black talc is destroyed, and the $\mathrm{Mg}$ and $\mathrm{Si}$ are converted to amorphous $\mathrm{MgO}$ and $\mathrm{SiO}_{2}$. Moreover, alkaline and acidic solutions can leach $\mathrm{SiO}_{2}$ and $\mathrm{MgO}$, respectively. Specifically, $1 \mathrm{~g}$ of different calcined samples was added into $25 \mathrm{~mL}$ of $2 \mathrm{M} \mathrm{H}_{2} \mathrm{SO}_{4}$ solution and $25 \mathrm{~mL}$ of $4 \mathrm{M} \mathrm{NaOH}$ solution, respectively, and stirred at $70{ }^{\circ} \mathrm{C}$ for $4 \mathrm{~h}$. Finally, the leached material was filtered and washed, and the filtrates were analyzed using the inductively coupled plasma technique.

\subsubsection{Characterizations}

The chemical composition of black talc was examined using a wavelength dispersive X-ray fluorescence spectrometer (XRF, PANalytical Axios, Amsterdam, the Netherlands). Thermogravimetric and differential scanning calorimetric studies (TG/DSC, NETZSCH STA 449F3, Selb, Germany) were carried out to determine the thermal stability of raw black talc at a heating rate of $10{ }^{\circ} \mathrm{C} / \mathrm{min}$ from 30 to $1000{ }^{\circ} \mathrm{C}$. Thermal analysis using thermogravimetry-mass spectrometry (TG-MS, Rigaku thermo plus EV2, Tokyo, Japan) provides qualitative and quantitative information on the thermal decomposition pathway and thermal stability of pristine black talc. The test temperature ranged from 25 to $1000^{\circ} \mathrm{C}$, and the heating rate was $10^{\circ} \mathrm{C} / \mathrm{min}$. In situ variable temperature X-ray diffraction (XRD, PANalytical Empyrean, Amsterdam, the Netherlands) was used in real time to track physical phase composition and crystal structure changes in raw black talc during the thermal treatment process, in which the sample was heated from 30 to $1000{ }^{\circ} \mathrm{C}$ (heating rate $\left.10^{\circ} \mathrm{C} / \mathrm{min}\right)$. Each target temperature was held for $10 \mathrm{~min}$ for scanning ranging from $5^{\circ}$ to $90^{\circ}$, with a speed of $4^{\circ} / \mathrm{min}$. Using in situ Fourier transform infrared (FTIR, Thermo Scientific Nicolet iS50, Waltham, MA, USA) spectrometry, the infrared spectral changes of calcined samples were recorded with a wavenumber range of $4000-550 \mathrm{~cm}^{-1}$, scan number 64 , and resolution $8 \mathrm{~cm}^{-1}$. In addition, the samples Talc, T800, and T900 were tested separately. A gas sorption instrument (BET, Quantachrome NOVA 4200e, Boynton Beach, FL, USA) was used to study the $\mathrm{N}_{2}$ adsorption-desorption isotherms of samples. The Brunauer-Emmett-Teller and Barett-Joyner-Halenda methods were used to calculate the specific surface area and pore size distribution. A laser particle size distributor (Bettersize, BT-9300HT, Dandong, China) measured the particle size of different calcined samples. Inductively coupled plasma emission spectrometry (ICP, Spectro Blue II, Kleve, Germany) was used to quantify amorphous $\mathrm{SiO}_{2}$ and $\mathrm{MgO}$ in samples. The Zeta potential of samples at various $\mathrm{pH}$ values was determined using a nanoparticle size and Zeta potential analyzer (Malvern Zetasizer Nano ZS/ZEN3500, Malvern, UK). $\mathrm{NaOH}$ and $\mathrm{H}_{2} \mathrm{SO}_{4}$ solutions were used to adjust the $\mathrm{pH}$. The morphologies of samples were observed using a field emission scanning electron microscope (SEM, ZEISS Gemini SEM 300, Oberkochen, Germany) equipped with an energy-dispersive spectrometer (EDS) at a $2 \mathrm{kV}$ accelerating voltage. The sample was observed using a transmission electron microscope (TEM, JEOL JEM-2100F, Tokyo, Japan) at a voltage of $200 \mathrm{kV}$; the SEAD patterns can be utilized to estimate the sample's degree of crystallization. 


\section{Results and Discussion}

\subsection{Thermal Stability of Raw Black Talc}

Thermal analysis techniques were utilized to investigate heat absorption, exotherm, and mass changes in minerals during thermal treatment. The TG-DSC curves show that the mass loss of pristine black talc can be divided into four recession stages during the calcination process $\left(30-1000{ }^{\circ} \mathrm{C}\right.$ ) (Figure 1a). During the first stage (from 30 to $165^{\circ} \mathrm{C}$ ), the quality loss is $0.32 \%$, primarily due to black talc lacking interlayer water and having a feeble physical adsorbed water-binding force, indicating its weight loss below $165^{\circ} \mathrm{C}$. The intensity of water $(m / z=18)$ in the MS curves is close to 0 at about $152^{\circ} \mathrm{C}$ (Figure $1 \mathrm{~b}$ ), indicating the disappearance of adsorbed water. The second stage is $165-580^{\circ} \mathrm{C}$, with a quality loss of $0.65 \%$ and a weak endothermic valley appearing at $336.7^{\circ} \mathrm{C}$. Clearly, there is a peak in the $m / z=44 \mathrm{MS}$ curve at $600{ }^{\circ} \mathrm{C}$ (Figure $1 \mathrm{~b}$ ), which shows that $\mathrm{CO}_{2}$ is increasing. Thus, the oxidation of interlayer organic carbon within black talc occurs at this stage [31]. The maximum quality loss of mineral at $580-1000{ }^{\circ} \mathrm{C}$ (mass loss of $7.02 \%$ ) corresponds to the decomposition reaction of ore. In particular, the decomposition reaction of ore includes the decomposition of dolomite and talc. The TG curve shows a sharp decrease in mass at $580{ }^{\circ} \mathrm{C}$, and two endothermic valleys appear at $629.7^{\circ} \mathrm{C}$ and $657.2^{\circ} \mathrm{C}$, which is attributed to the decomposition of dolomite (Equation (1)). Weight loss is 3.30\% from 740 to $1000{ }^{\circ} \mathrm{C}$, with endothermic valleys at $770.2^{\circ} \mathrm{C}$ and $787.2{ }^{\circ} \mathrm{C}$ due to re-decomposition of dolomite (Equation (2)) and the endothermic valley at $846.7^{\circ} \mathrm{C}$ caused by dihydroxylation. In addition, there is an endothermic valley at $920.7^{\circ} \mathrm{C}$, and the TG curve tends to flatten, while the talc phase transitions to enstatite (Equation (3)) [32].

$$
\begin{aligned}
\mathrm{CaMg}\left(\mathrm{CO}_{3}\right)_{2} & \rightarrow \mathrm{CaCO}_{3}+\mathrm{MgO}+2 \mathrm{CO}_{2} \uparrow \\
\mathrm{CaCO}_{3} & \rightarrow \mathrm{CaO}+\mathrm{CO}_{2} \uparrow \\
\mathrm{Mg}_{3}\left[\mathrm{Si}_{4} \mathrm{O}_{10}\right](\mathrm{OH})_{2} & \rightarrow 3 \mathrm{MgSiO}_{3}+\mathrm{SiO}_{2}+\mathrm{H}_{2} \mathrm{O} \uparrow
\end{aligned}
$$

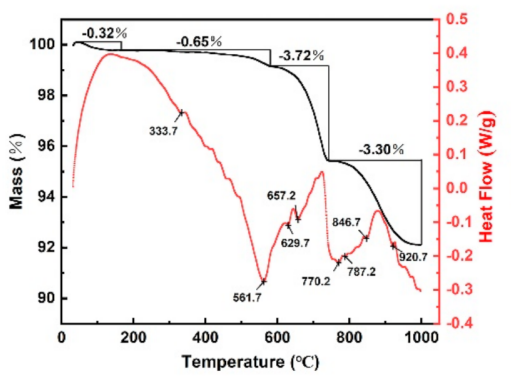

b

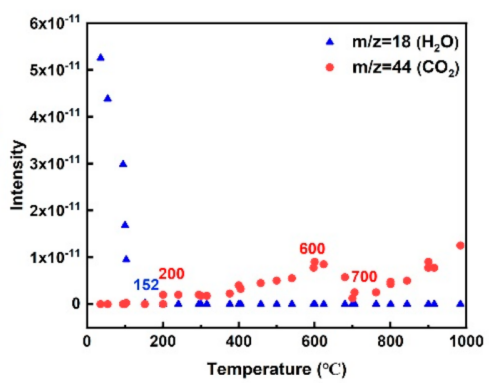

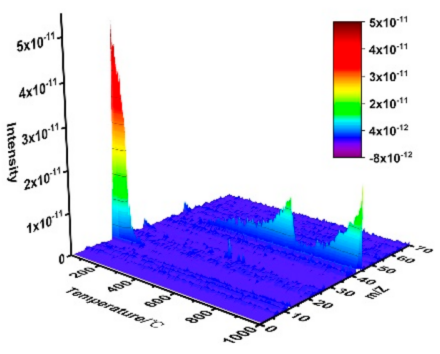

Figure 1. (a) TG-DSC curves, (b) $m / z=18,44$ MS curves, and (c) MS desorption yields of pristine black talc.

\subsection{In Situ XRD Analysis}

Changes in mineral crystal structures during thermal treatment are tracked in real time via in situ XRD to identify the influence of temperature on black talc structures. Figure 2a shows the WAXRD patterns of black talc and partial enlargement of the peak at $2 \theta=27-29^{\circ}$ (Figure 2a). The $\mathrm{d}(006)$ values and peak positions of black talc were combined to reflect crystallographic structure changes during calcination (Figure 2b). Combined with TG-DSC and TG-MS results, Figure $2 \mathrm{a}, \mathrm{b}$ distinctly reveals the evolution process of talc at $30-1000{ }^{\circ} \mathrm{C}$ : (1) dehydration: below $200^{\circ} \mathrm{C}$, the intensity of water $(m / z=18)$ in the MS curves is close to 0 (Figure $1 \mathrm{~b}$ ), and the adsorbed water of black talc is completely removed [31]. However, the $d(006)$ value of the calcined sample is not reduced (Figure $2 b$ ), which means that water is absorbed on the surface of the mineral and does not enter the layer. (2) Decomposition: with temperature increasing to $550{ }^{\circ} \mathrm{C}$, there is an obvious peak in the $\mathrm{m} / z=44$ MS curve (Figure $1 \mathrm{~b}$ ), which indicates the oxidative decomposition of organic carbon between black 
talc layers [33]. There is a larger $\mathrm{d}(006)$ value for $\mathrm{T} 550(0.315 \mathrm{~nm})$ than that for raw black talc $(0.313 \mathrm{~nm})$ due to the $\mathrm{CO}_{2}$ caused by the decomposition of organic carbon escape, leading to the expansion and deformation of black talc structures. In addition, compared with the XRD patterns of Talc, T100, T200, T300, T400, T500, and T600, there is a slight change in T700. The peaks at $2 \theta=30.62^{\circ}$ and $2 \theta=40.92^{\circ}$ corresponding to the base reflections on (104) and (113) planes of dolomite become fainter and weaker, eventually disappearing entirely from T750 [34]. In conclusion, organic carbon decomposition separates black talc layers, and dolomite decomposes entirely below $750{ }^{\circ} \mathrm{C}$, which is compatible with the TG and TG-MS study results. (3) Phase transition: after the calcination of pristine black talc at $800{ }^{\circ} \mathrm{C}$, the peak corresponding to the base reflections on (006) gradually becomes weak, indicating that black talc begins to go through dihydroxylation [35]. The reflections of the enstatite structure appear in the XRD pattern of T950, indicating the mineral phase transition [36]. The XRD pattern of T1000 is utterly devoid of structural reflections of talc, suggesting a complete transformation to the enstatite phase. Ohlberg and Strickler defined the crystallinity index (CI) [37], which includes the peak intensities and background to quantify the deformation of the crystal structure [38]. The specific index is:

$$
\mathrm{CI}=\mathrm{B}_{0} \mathrm{I} /\left(\mathrm{I}_{0} \mathrm{~B}\right) \times 100 \%
$$

where $C I=$ crystallinity index,$I_{0}=$ peak intensity for referenced sample, $B_{0}=$ background intensity for referenced sample, $\mathrm{I}=$ peak intensity for experimental sample, and $\mathrm{B}=$ background intensity for experimental sample. Here, to eliminate the influence of moisture in the air on the crystallinity of the samples, T100 was used as a reference sample [39]. Below $700{ }^{\circ} \mathrm{C}$, the crystallinity index of black talc decreases from 100\% (T100) to 79.9\% (T700), and T750 and T800 remain relatively constant (Figure $2 \mathrm{c}$ ). The relative crystallinity index of black talc, in particular, drops drastically over $800{ }^{\circ} \mathrm{C}$, from $75.8 \%$ to $51.0 \%$ at $900{ }^{\circ} \mathrm{C}$, indicating that the dihydroxylation reaction of black talc has commenced. Noteworthily, the relative crystallinity index of T950 plummets to $27.3 \%$, and the (006) peak in the XRD pattern almost disappears, indicating that black talc cannot maintain a complete crystal structure at $950{ }^{\circ} \mathrm{C}$, and more amorphous $\mathrm{SiO}_{2}$ and $\mathrm{MgO}$ appear in the structure. Black talc then undergoes a phase transition and evolves into enstatite (Equation (3)). Existing research has reported that dihydroxylation processes in talc take place at temperatures as high as approximately 850-900 ${ }^{\circ} \mathrm{C}$ [40]. However, it has been observed that dihydroxylation of black talc begins at $800{ }^{\circ} \mathrm{C}$; additionally, black talc has a lower degree of crystallization and poor thermal stability compared with conventional talc.

The full width $(\beta)$ at half the maximum of the diffraction peak changes as temperature increases due to lattice deformation produced by phase transformation and oxidative breakdown of organic carbon. Scherrer established a formula (Equation (5)) for the full width at the half maximum $\left(\beta_{\mathrm{d}}\right)$ of the diffraction peak to explain the relationship between grain size (D) and $\beta_{\mathrm{d}}[41]$. The strain induced in powders due to crystal imperfection and distortion was calculated using the formula (Equation (6)) [42].

$$
\begin{aligned}
& \beta_{\mathrm{d}}=\frac{K \lambda}{\mathrm{D} \cos \theta} \\
& \beta_{\mathrm{s}}=4 \varepsilon \tan \theta
\end{aligned}
$$

where $k$ is the shape factor, $\lambda$ is the wavelength of the $X$-ray, D is the grain size, $\theta$ is the diffraction angle, and $\varepsilon$ is the lattice deformation degree.

$$
\beta \cos \theta=4 \varepsilon \sin \theta+\frac{K \lambda}{\mathrm{D}}
$$

Taking the Kosch diffraction intensity distribution theory as the basis, the above two equations (Equations (5) and (6)) can be superimposed into Equation (7) which is called Williamson-Hall equation [43]. 


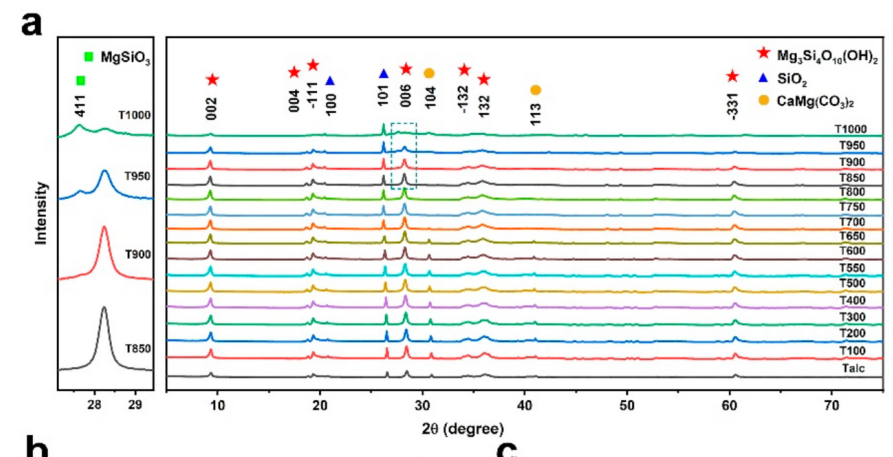

b
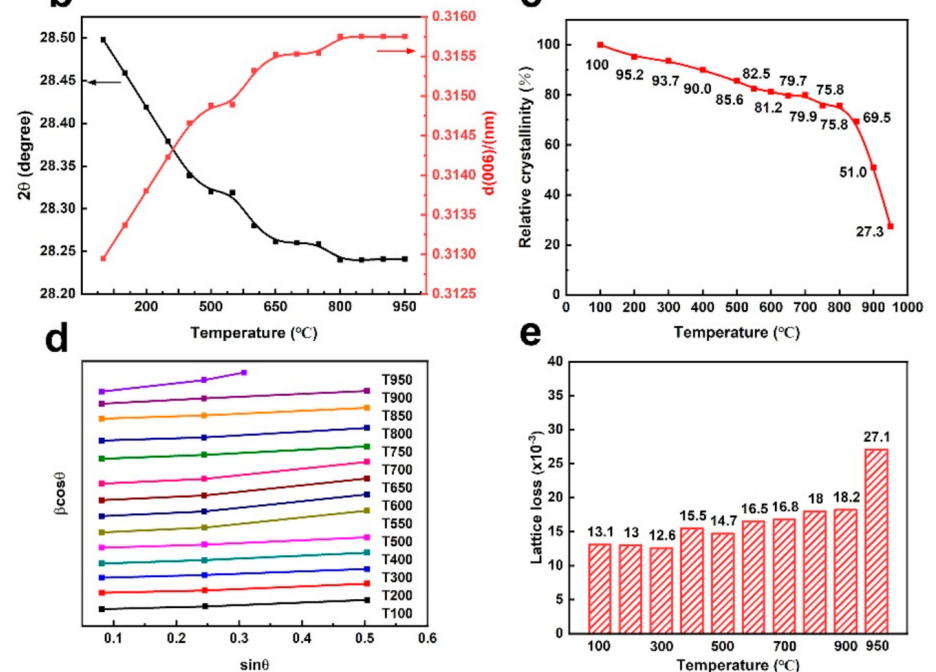

Figure 2. (a) In situ XRD patterns, (b) corresponding d(006) values and peak positions, (c) relative crystallinity, (d) $\beta \cos \theta \sim \sin \theta$ curves, and (e) lattice deformation degree of black talc upon calcination.

Based on previous studies, the relationship between lattice deformation degree and temperature of minerals is studied. By calculating the full width $(\beta)$ at the half maximum value of the diffraction peak of the crystal plane on the XRD pattern, the straight line of $\beta \cos \theta \sim \sin \theta$ can be obtained (Figure 2d). According to Equation (7), the slope of the line in Figure $2 \mathrm{~d}$ reflects the lattice deformation of different samples. Figure $2 \mathrm{~d}$,e demonstrates that the $\beta \cos \theta \sim \sin \theta$ fitting lines of T100, T200, and T300 are almost identical straight lines with remarkably similar slopes. The slope increases with temperature, and a significant increase occurs at $800{ }^{\circ} \mathrm{C}$, indicating that dihydroxylation of black talc has begun. The slope of T950 substantially increases, the crystallographic structure of black talc becomes exceedingly disordered, and the black talc phase transforms into the enstatite.

\subsection{FTIR Spectrum}

Earlier studies reported vibrational bands of talc and other clay minerals. In situ FTIR was used to characterize the variation trend in the vibrational bands of black talc during thermal treatment (Figure 3). In ideal talc, three $\mathrm{Mg}$ ions are linked to the hydroxyl ion symmetrically, and the $\mathrm{O}-\mathrm{H}$ stretching band is related to the $\mathrm{Mg}_{3} \mathrm{OH}$ appearing at $3676 \mathrm{~cm}^{-1}$ [44]. There is a broadband at $3420 \mathrm{~cm}^{-1}$ due to an overlap in the H-O-H bond's symmetric and asymmetric stretching vibrations in $\mathrm{H}_{2} \mathrm{O}$. The weak band at $1440 \mathrm{~cm}^{-1}$ is caused by antisymmetric stretching of $-\mathrm{CO}_{3}$ in carbonate. The sharp band at $1017 \mathrm{~cm}^{-1}$ associated with the stretching vibration of $\mathrm{Si}-\mathrm{O}-\mathrm{Si}$ confirms the existence of $\mathrm{SiO}_{4}$ tetrahedral in the crystal structure of black talc [40]. The peaks at $802 \mathrm{~cm}^{-1}$ and $785 \mathrm{~cm}^{-1}$ are caused by the symmetrical stretching of $\mathrm{Si}-\mathrm{O}-\mathrm{Si}$ in quartz. Absorption-associated fundamental $\mathrm{OH}$ vibrations have been recognized through hydrogen-deuterium substitution experiments. The band near $669 \mathrm{~cm}^{-1}$ is attributed to $\mathrm{OH}^{-}$libration [45]. 

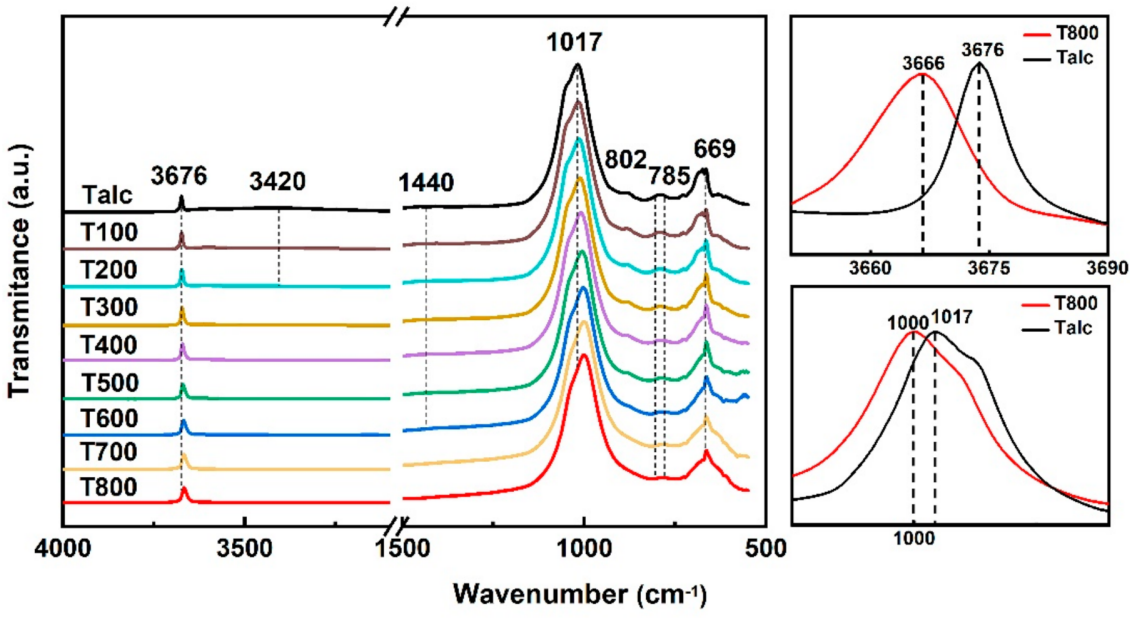

Figure 3. In situ FTIR spectra of black talc calcined at different temperatures and peaks of Talc and T800 near $1017 \mathrm{~cm}^{-1}$ and $3674 \mathrm{~cm}^{-1}$.

Dehydrogenation and structural changes can occur when minerals are heated to high temperatures, such as in rectorite dihydroxylation between 500 and $700{ }^{\circ} \mathrm{C}$ [46]. Paradoxically, thermal treatment has little influence on the $\mathrm{OH}$ bands of black talc below $800{ }^{\circ} \mathrm{C}$. The FTIR spectra of the samples remained unchanged at $200^{\circ} \mathrm{C}$, with only the broadband associated with $\mathrm{H}-\mathrm{O}-\mathrm{H}$ disappearing at $3420 \mathrm{~cm}^{-1}$. At this point, the mineral is completely dehydroxylated. Meanwhile, the weak peak of T700 at $1440 \mathrm{~cm}^{-1}$ has disappeared completely, indicating the occurrence of dolomite decomposition in the mineral. $\mathrm{The}^{-}$ libration at $669 \mathrm{~cm}^{-1}$ decreases in the calcined sample T800. Furthermore, the position of $\mathrm{O}-\mathrm{H}$ stretching associated with $\mathrm{Mg}_{3} \mathrm{OH}$ species shifts to the lower band, from $3676 \mathrm{~cm}^{-1}$ to $3666 \mathrm{~cm}^{-1}$. Simultaneously, the vibration bands at $1017 \mathrm{~cm}^{-1}$ attributed to the Si-O-Si also shift to the low band, from $1017 \mathrm{~cm}^{-1}$ to $1000 \mathrm{~cm}^{-1}$. These changes indicate that the structure of talc has changed after thermal treatment.

As a result of the above analysis, the crystal structure of black talc changes at $800{ }^{\circ} \mathrm{C}$. Despite this, the cause of talc's structural alteration is unknown. Consequently, when the temperature was above $800^{\circ} \mathrm{C}$, the structural alterations of materials, particularly changes in chemical groups, were explored in depth using FTIR analysis. The FTIR absorption spectra and the corresponding band assignments of Talc, T800, and T900 are shown in Figure 4. Compared with Talc, the intensity of peaks at 3676 and $1017 \mathrm{~cm}^{-1}$ decreases until they disappear. Simultaneously, several small infrared absorption peaks appear at $800-900 \mathrm{~cm}^{-1}$, caused by dihydroxylation of black talc. Moreover, dihydroxylation causes the vibration peak of $\mathrm{OH}^{-}$at $669 \mathrm{~cm}^{-1}$ to weaken and fragment into multiple minor peaks. Therefore, the FTIR test results of black talc heating indicate that black talc begins to go through dihydroxylation and crystal decomposition at $800^{\circ} \mathrm{C}$ as well.

a

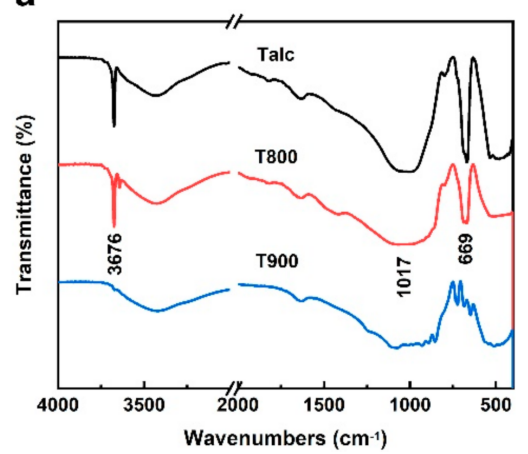

b

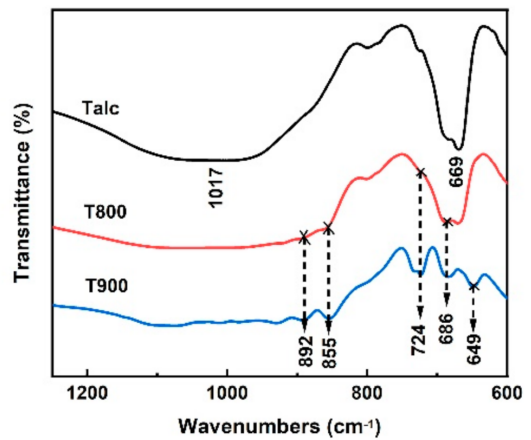

Figure 4. FTIR spectra of Talc, T800, and T900 from (a) 4000 to $400 \mathrm{~cm}^{-1}$, (b) 1250 to $600 \mathrm{~cm}^{-1}$. 


\subsection{Physical Property Measurements}

According to the IUPAC classification, there is a slight H3 hysteresis loop in Figure 5a, and the shape of the $\mathrm{N}_{2}$ adsorption/desorption isotherm indicates that the black talc adsorption type is a type II adsorption branch. The slotted holes formed by stacking flake particles are common in black talc. When $\mathrm{P} / \mathrm{P}_{0}$ is at a lower stage, the adsorption isotherm increases with an increase in $\mathrm{P} / \mathrm{P}_{0}$, and the black talc pore wall surface is covered with a monolayer of nitrogen molecules in a single layer. The multilayer adsorption of nitrogen molecules contributes to the adsorption isotherm rising sharply from $\mathrm{P} / \mathrm{P}_{0}=0.9$, indicating that the mesopores in the samples have a uniform pore size distribution and are well ordered. Moreover, the pore size distribution curves show small mesopores with a $3-4.5 \mathrm{~nm}$ pore size in black talc. After thermal treatment, the adsorption capacity and pore size of black talc do not change significantly below $700{ }^{\circ} \mathrm{C}$, and the pore size distribution of T700 is around $4.0 \mathrm{~nm}$. Although the organic carbon decomposes between the mineral layers at this time, it does not change the specific surface area of the mineral significantly due to the small amount involved. However, due to the dihydroxylation of minerals, the pore size and adsorption volume of the sample show a certain degree of reduction at $800{ }^{\circ} \mathrm{C}$. Interestingly, even at $1000^{\circ} \mathrm{C}, \mathrm{T} 1000$ still has adsorption capacity. Its pore size distribution curve has a clear peak at $4.0 \mathrm{~nm}$, suggesting that talc can still maintain a certain pore structure at high temperatures.

a

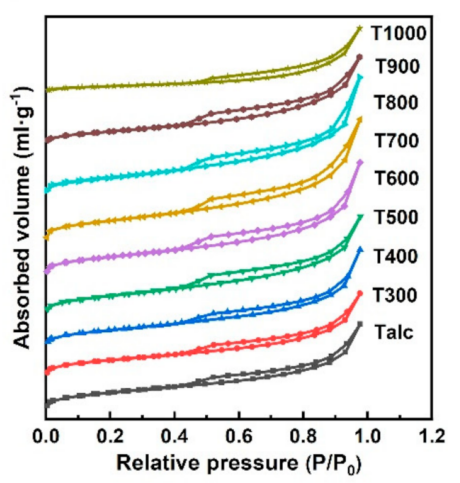

b

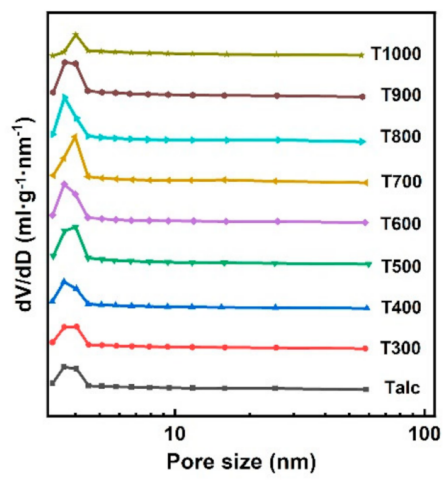

C

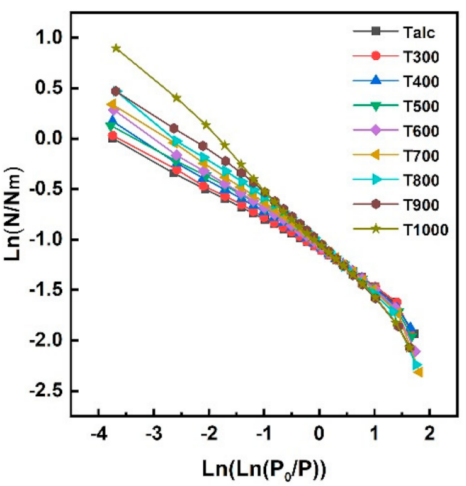

Figure 5. (a) $\mathrm{N}_{2}$ adsorption/desorption isotherm curves; (b) BJH pore size distribution curves of pristine black talc and calcined samples at different temperatures; (c) A log-log plot of N/N $\mathrm{N}_{\mathrm{m}}$ vs. $\ln$ $\mathrm{P} / \mathrm{P}_{0}$ showing the linear range where fractal behavior is observed.

In addition, the fractal concept describes the surface roughness of mineral structures. Furthermore, the fractal dimension $\mathrm{D}$ can be derived from adsorption measurements, calculated via the following equation [47].

$$
\begin{aligned}
& \frac{\mathrm{N}}{\mathrm{N}_{\mathrm{m}}} \approx\left[\operatorname{RT} \ln \left(\frac{P_{0}}{\mathrm{P}}\right)\right]^{-(3-D) / 3} \\
& \frac{\mathrm{N}}{\mathrm{N}_{\mathrm{m}}} \approx\left[\operatorname{RT} \ln \left(\frac{P_{0}}{\mathrm{P}}\right)\right]^{-(3-D)}
\end{aligned}
$$

where $\mathrm{N} / \mathrm{N}_{\mathrm{m}}$ represents the surface fractional coverage, and $\mathrm{P}$ and $\mathrm{P}_{0}$ are, respectively, the equilibrium and saturation pressures of the adsorbate. From the isotherm, one can generate a plot of $\ln \left(\mathrm{N} / \mathrm{N}_{\mathrm{m}}\right)$ vs. $\ln \left[\ln \left(\mathrm{P}_{0} / \mathrm{P}\right)\right]$ (Figure $5 \mathrm{c}$ ). The exponents in Equations (8) and (9) can be obtained from the slope $\mathrm{S}$ of this plot. Usually, $2 \leq \mathrm{D}<3$, and a higher $\mathrm{D}$ value suggests a more wiggle- and space-filling surface. Thus, Equation (8) predicts that we should have $-1 / 3 \leq \mathrm{S}<0$, but Equation (9) says that $-1 \leq \mathrm{S}<0$. Table 2 shows that the fractal constant of minerals decreases with the increase in temperature, indicating that the surface of mineral structure becomes smoother. 
Table 2. Surface fractal dimensions of samples obtained using fractal FHH isotherm equations.

\begin{tabular}{ccccc}
\hline Samples & $\begin{array}{c}\text { Surface Area } \\
\left.\mathbf{( m}^{\mathbf{2}} \mathbf{g}\right)\end{array}$ & Slope & $\begin{array}{c}\text { D from } \\
\text { Equation (8) }\end{array}$ & $\begin{array}{c}\text { D from } \\
\text { Equation (9) }\end{array}$ \\
\hline Talc & 18.8 & -0.325 & 2.03 & 2.68 \\
T300 & 17.7 & -0.333 & 2.00 & 2.67 \\
T400 & 17.6 & -0.360 & 1.92 & 2.64 \\
T500 & 18.5 & -0.368 & 1.90 & 2.63 \\
T600 & 17.9 & -0.397 & 1.81 & 2.60 \\
T700 & 17.9 & -0.430 & 1.71 & 2.57 \\
T800 & 15.0 & -0.455 & 1.63 & 2.54 \\
T900 & 11.2 & -0.474 & 1.58 & 2.53 \\
T1000 & 5.3 & -0.550 & 1.35 & 2.45 \\
\hline
\end{tabular}

Previous studies have shown that crystal lattice distortion and chemical bond fracture of clay minerals increased the specific surface area and surface defects [48,49], leading to an increase in reactivity $[50,51]$. When the temperature exceeds $800{ }^{\circ} \mathrm{C}$, the particle size of black talc increases from $21.94 \mu \mathrm{m}$ (Talc) to $28.17 \mu \mathrm{m}$ (T800) due to dihydroxylation (Figure 6a). Meanwhile, a considerable amount of amorphous $\mathrm{SiO}_{2}$ and $\mathrm{MgO}$ appears (Figure $6 \mathrm{~b}$ ), and mineral activity significantly improves. Combined with the analysis results of in situ XRD, the relative crystallinity index of T950 is $27.3 \%$. The particle size of $\mathrm{T} 1000$ is $32.78 \mu \mathrm{m}$, and the amorphous silica content is very high. The results of the above investigation demonstrate that thermal treatment can cause structural collapse and activity improvement of black talc.

a

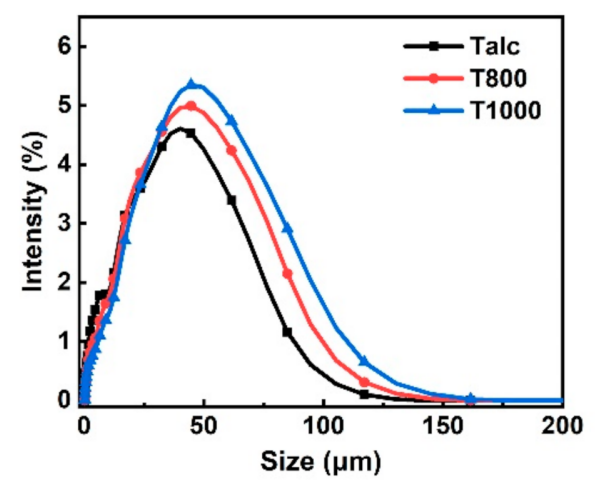

b

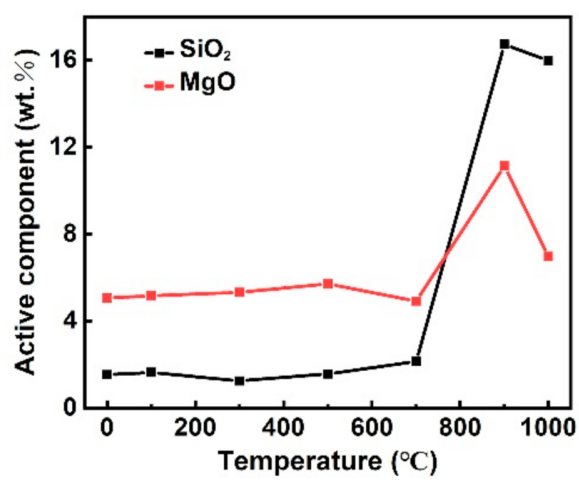

Figure 6. (a) particle size distribution of Talc, T800, and T1000; (b) relationship between the content of amorphous $\mathrm{SiO}_{2}$ and $\mathrm{MgO}$ and the calcination temperature of black talc.

\subsection{Surface Zeta Potential}

Calcination can affect the surface potential of black talc, and its change trend can be measured via Zeta potential. The electrokinetic phenomena of different black talc calcination samples were investigated in this paper, which measured the Zeta potential of black talc samples in different $\mathrm{pH}$ suspensions. The results showed that the Zeta potential of samples remained stable in different $\mathrm{pH}$ solutions, indicating that the hydroxyl deprotonation ability of black talc surface was weak. Among them, T800 has less negative surface potential (Figure 7a). When $\mathrm{pH}=2$, the surface potential of black talc calcined at different temperatures changes little (Figure 7b). The surface potential of T800 is half that of natural talc, which is associated with the dihydroxylation of black talc. Moreover, the Zeta potential of sample T800 basically did not change with the change of $\mathrm{pH}$, indicating that the $-\mathrm{OH}$ removal also reduced the ability of mineral surface deprotonation. 
a

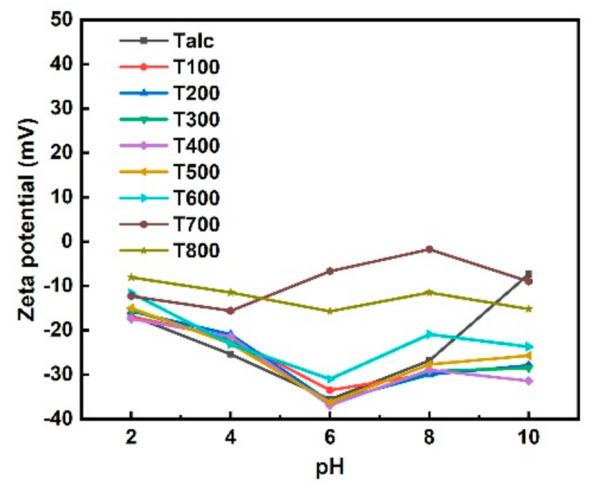

b

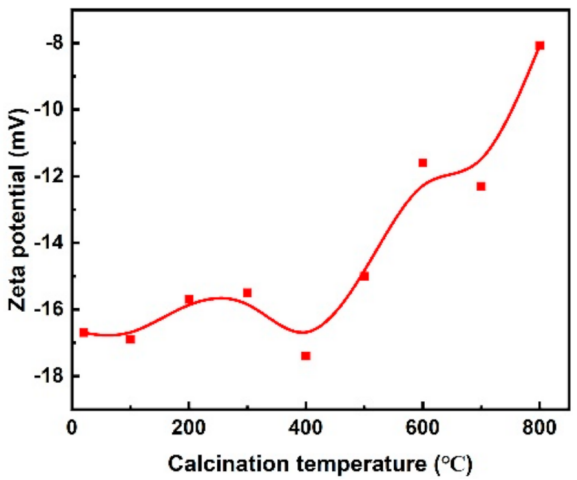

Figure 7. Zeta potential of pristine black talc and calcined samples at (a) different $\mathrm{pH}$ values, (b) $\mathrm{pH}=2$.

\subsection{Morphological Variation of Black Talc upon Thermal Treatment}

Obviously, color change is the most obvious change that black talc undergoes during calcination. With an increase in temperature, the whiteness of minerals increases significantly (Figure 8). Uneven layered structures can be observed at the edges of black talc particles via scanning electron microscopy (SEM, Figure 9). The crystal of black talc is an irregular and small flake, and the radial size of the flake is tens to hundreds of nanometers. Compared with natural black talc, calcined black talc layers become fluffier (Figure 9c,d). Significantly, black talc can still maintain a good lamellar structure at high temperatures (Figure 9e,f), indicating that black talc has good thermal stability. In addition, many fine particles appear on the mineral surface during heat treatment.

Pristine black talc crystal particles are composed of lamellar layers with small diameters, thin thickness, and poor crystallinity (Figure 10). Noticeably, black talc maintains its layered structure during thermal treatment. In addition, T900 and T1000 crystals are mostly round and irregular in shape. Selected area electron diffraction (SAED) images showed a good crystal structure of samples calcined at temperatures below $700{ }^{\circ} \mathrm{C}$ (Figure $10 \mathrm{a}-\mathrm{d}$ ). Significant deterioration of the mineral crystal structure occurs at $900{ }^{\circ} \mathrm{C}$ (Figure $10 \mathrm{e}$ ), which is due to the destruction of the crystal structure caused by dihydroxylation. Thus, TEM and SEAD images of calcined samples at different temperatures further confirm the increase in the amorphous degree of black talc during thermal treatment. Overall, calcined at a temperature range of 30 to $1000{ }^{\circ} \mathrm{C}$, pristine black talc will undergo four successive stages (Figure 11): (1) 30-165 ${ }^{\circ} \mathrm{C}$, dehydration; (2) 165-580 ${ }^{\circ} \mathrm{C}$, organic carbon decomposition; (3) $800-900{ }^{\circ} \mathrm{C}$, dihydroxylation; and (4) $900-1000{ }^{\circ} \mathrm{C}$, phase transitions.

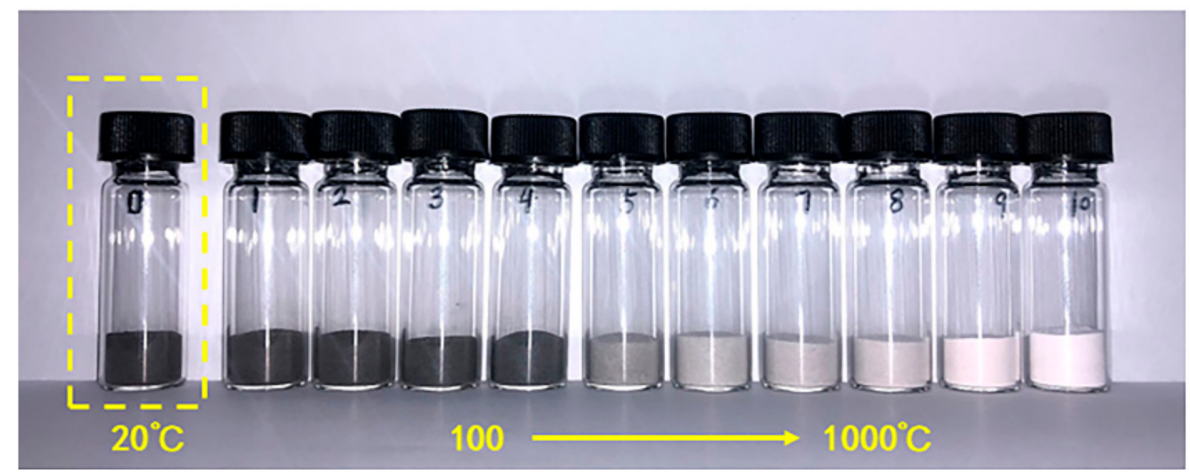

Figure 8. Whiteness change of black talc during heat treatment. 

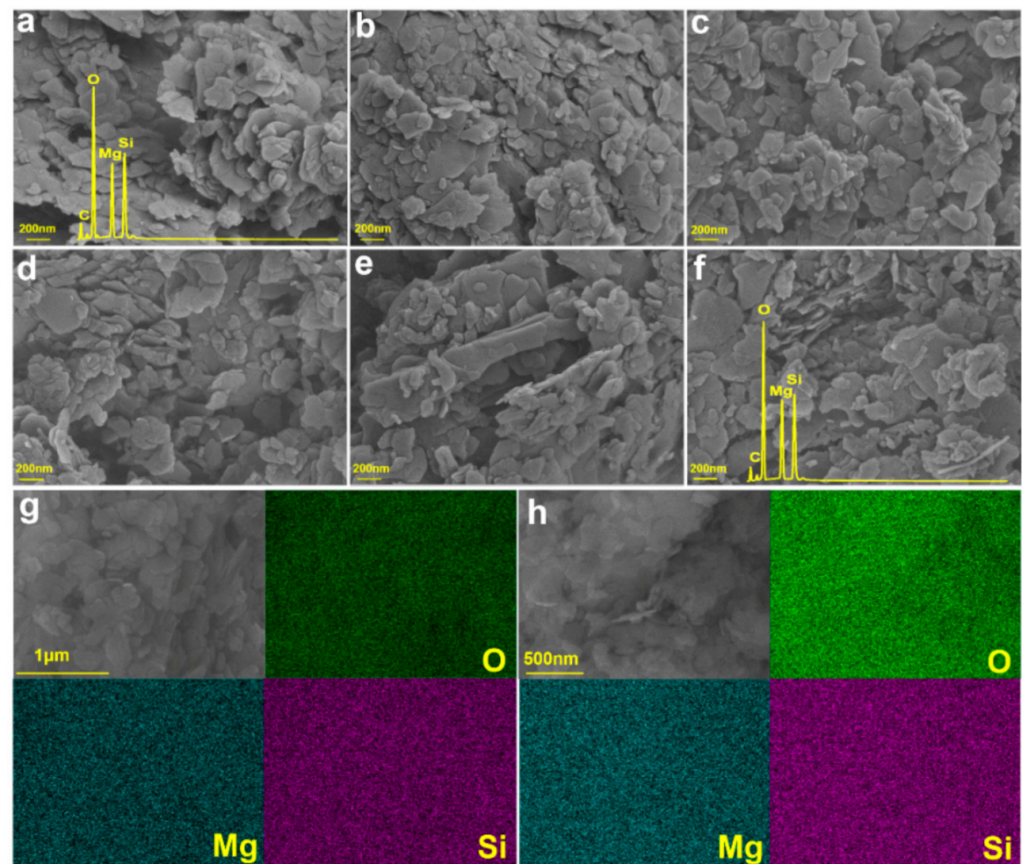

Figure 9. SEM images of (a) Talc, (b) T300, (c) T500, (d) T700, (e) T900, and (f) T1000; the mapping of (g) Talc and (h) T1000 samples.

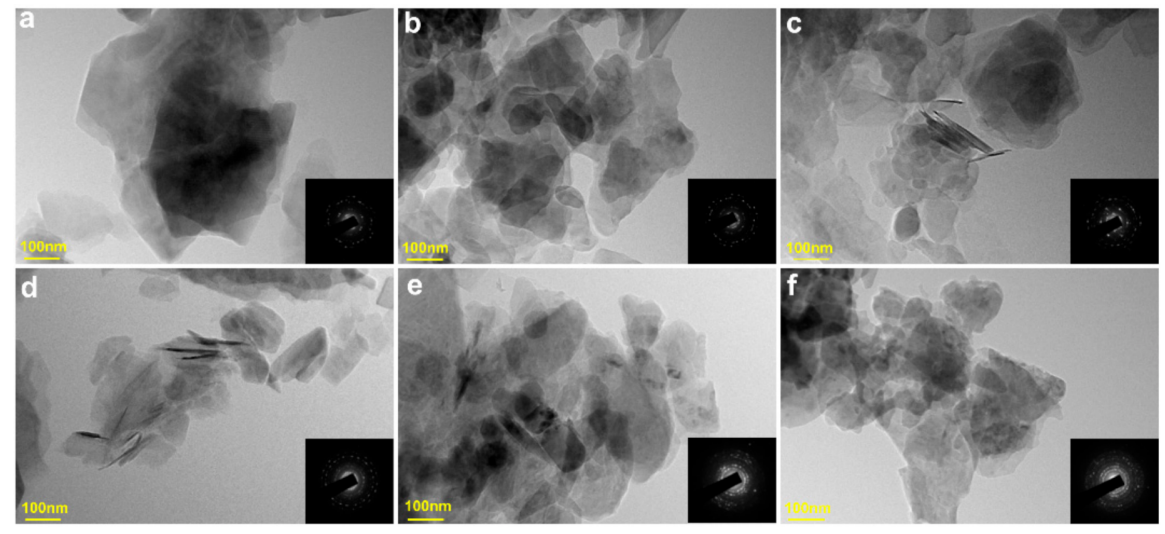

Figure 10. TEM images of (a) Talc, (b) T300, (c) T500, (d) T700, (e) T900, and (f) T1000.

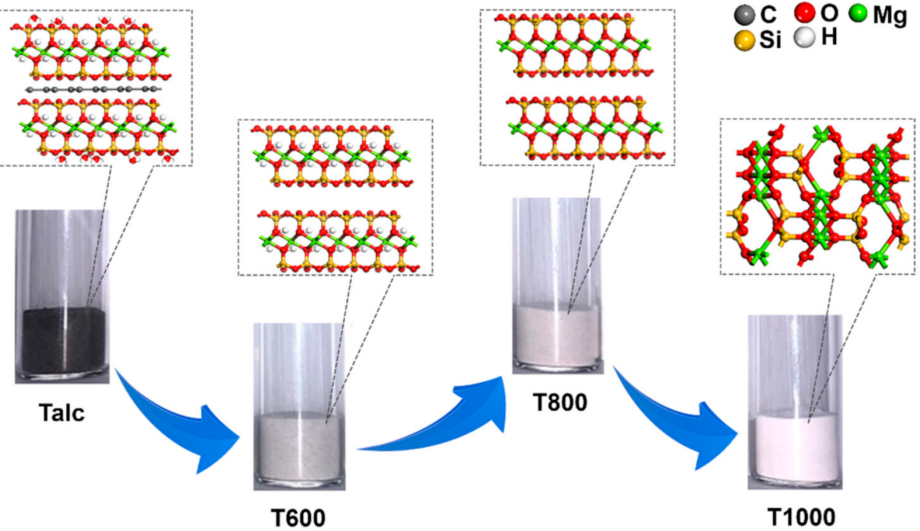

Figure 11. Schematic diagram of black talc evolution during thermal treatment. 


\section{Conclusions}

The evolution of the crystal structure, physicochemical properties, and morphology of black talc during thermal treatment were systematically studied. The first notable structural change in black talc is the widening layer spacing produced by $\mathrm{CO}_{2}$ escaping from organic carbon decomposition. Dehydration does not change the structure of black talc because water is adsorbed on the surface of the ore in small amounts. Dihydroxylation of black talc begins at $800{ }^{\circ} \mathrm{C}$, and the temperature is lower than that of conventional talc. At this stage, the specific surface area and pore size of the mineral decrease slightly but more than they do in original black talc, and the layered structure can still be maintained. Black talc then goes through phase transitions and becomes enstatite, and the reflections associated with the enstatite structure emerge in the XRD pattern of T950. Meanwhile, calcined minerals have a larger grain size and higher amorphous $\mathrm{SiO}_{2}$ and $\mathrm{MgO}$ content. In addition, the surface potential of black talc also changed during thermal treatment: T800 is half that of natural talc. Overall, thermal treatment improves the surface activity and whiteness of black talc. Our results systematically confirm the evolution of black talc upon thermal treatment, providing a theoretical basis for the preparation of functional composites from black talc. Different nanoparticles can be assembled on the surface of calcined black talc, with the aim to realize the functionalization of black talc. Functionalized modified black talc can be applied to many high-tech fields, such as biology, the environment, and catalysis, thus greatly improving the application value of black talc.

Author Contributions: Conceptualization, H.Y. and Y.M.; methodology, Y.M. and W.X.; validation, Y.M. and H.Y.; formal analysis, Y.M.; investigation, Y.M.; resources, Y.M. and H.Y.; data curation, Y.M. and H.W.; writing—original draft preparation, Y.M.; writing—review and editing, Y.M., S.M.T. and H.Y.; supervision, H.Y.; project administration, H.Y.; funding acquisition, H.Y. All authors have read and agreed to the published version of the manuscript.

Funding: This work was supported by the National Natural Science Foundation of China (51974367), the National Science Fund for Distinguished Young Scholars (51225403), the Fundamental Research Funds for the Central Universities, China University of Geosciences (Wuhan), and Hunan Provincial Innovation Foundation for Postgraduates (CX2017B057).

Conflicts of Interest: The authors declare no conflict of interest.

\section{References}

1. Belviso, C.; Cavalcante, F.; Niceforo, G.; Lettino, A. Sodalite, faujasite and A-type zeolite from 2:1 dioctahedral and 2:1:1 trioctahedral clay minerals. A singular review of synthesis methods through laboratory trials at a low incubation temperature. Powder Technol. 2017, 320, 483-497. [CrossRef]

2. Lin, J.; Zhong, B.; Luo, Y.; Jia, Z.; Hu, D.; Xu, T.; Jia, D. Enhancing interfacial and mechanical strength of styrene-butadiene rubber composites via in situ fabricated halloysite nanotubes/silica nano hybrid. Polym. Compos. 2019, 40, 677-684. [CrossRef]

3. Ren, J.; Dai, L.; Tao, L. Stabilization of heavy metals in sewage sludge by attapulgite. J. Air Waste Manag. Assoc. 2021, 71, 392-399. [CrossRef] [PubMed]

4. Hu, P.; Yang, H. Insight into the physicochemical aspects of kaolins with different morphologies. Appl. Clay Sci. 2013, 74, 58-65. [CrossRef]

5. Liu, D.; Peng, Y. Reducing the entrainment of clay minerals in flotation using tap and saline water. Powder Technol. 2014, 253, 216-222. [CrossRef]

6. Lvov, Y.; Wang, W.; Zhang, L.; Fakhrullin, R. Halloysite Clay Nanotubes for Loading and Sustained Release of Functional Compounds. Adv. Mater. 2016, 28, 1227-1250. [CrossRef]

7. Tully, J.; Yendluri, R.; Lvov, Y. Halloysite Clay Nanotubes for Enzyme Immobilization. Biomacromolecules 2016, 17, 615-621. [CrossRef]

8. Li, X.; Yang, Q.; Ouyang, J.; Yang, H.; Chang, S. Chitosan modified halloysite nanotubes as emerging porous microspheres for drug carrier. Appl. Clay Sci. 2016, 126, 306-312. [CrossRef]

9. Corrales, T.; Larraza, I.; Catalina, F.; Portolés, T.; Ramírez-Santillán, C.; Matesanz, M.; Abrusci, C. In Vitro Biocompatibility and Antimicrobial Activity of Poly( $\varepsilon$-caprolactone)/Montmorillonite Nanocomposites. Biomacromolecules 2012, 13, $4247-4256$. [CrossRef]

10. Wang, Z.; Zhu, W.; Qiu, Y.; Yi, X.; von dem Bussche, A.; Kane, A.; Gao, H.; Koski, K.; Hurt, R. Biological and environmental interactions of emerging two-dimensional nanomaterials. Chem. Soc. Rev. 2016, 45, 1750-1780. [CrossRef] 
11. Durak, G.M.; Taylor, A.R.; Walker, C.E.; Probert, I.; De Vargas, C.; Audic, S.; Schroeder, D.; Brownlee, C.; Wheeler, G.L. A role for diatom-like silicon transporters in calcifying coccolithophores. Nat. Commun. 2016, 7, 10543. [CrossRef]

12. Liu, S.; Yang, H. Composite of Coal-Series Kaolinite and Capric-Lauric Acid as Form-Stable Phase-Change Material. Energy Technol. 2015, 3, 77-83. [CrossRef]

13. Ding, W.; Ouyang, J.; Yang, H. Synthesis and characterization of nesquehonite $\left(\mathrm{MgCO}_{3} \cdot 3 \mathrm{H}_{2} \mathrm{O}\right)$ powders from natural talc. Powder Technol. 2016, 292, 169-175. [CrossRef]

14. $\mathrm{He}, \mathrm{X}$; Y Yang, H. Fluorescence and room temperature activity of $\mathrm{Y}_{2} \mathrm{O}_{3}:\left(\mathrm{Eu}^{3+}, \mathrm{Au}^{3+}\right)$ /palygorskite nanocomposite. Dalton Trans. 2015, 44, 1673-1679. [CrossRef]

15. Bonati, B.; Merusi, F.; Bochicchio, G.; Tessadri, B.; Polacco, G.; Filippi, S.; Giuliani, F. Effect of nanoclay and conventional flame retardants on asphalt mixtures fire reaction. Constr. Build. Mater. 2013, 47, 990-1000. [CrossRef]

16. Pack, S.; Kashiwagi, T.; Cao, C.; Korach, C.S.; Lewin, M.; Rafailovich, M.H. Role of Surface Interactions in the Synergizing Polymer/Clay Flame Retardant Properties. Macromolecules 2010, 43, 5338-5351. [CrossRef]

17. Adpakpang, K.; Patil, S.B.; Oh, S.M.; Kang, J.-H.; Lacroix, M.; Hwang, S.-J. Effective Chemical Route to 2D Nanostructured Silicon Electrode Material: Phase Transition from Exfoliated Clay Nanosheet to Porous Si Nanoplate. Electrochim. Acta 2016, $204,60-68$. [CrossRef]

18. Zhang, Y.; Long, M.; Huang, P.; Yang, H.; Chang, S.; Hu, Y.; Tang, A.; Mao, L. Intercalated 2D nanoclay for emerging drug delivery in cancer therapy. Nano Res. 2017, 10, 2633-2643. [CrossRef]

19. Long, M.; Zhang, Y.; Shu, Z.; Tang, A.; Ouyang, J.; Yang, $\mathrm{H} \mathrm{Fe}_{2} \mathrm{O}_{3}$ nanoparticles anchored on 2D kaolinite with enhanced antibacterial activity. Chem. Commun. 2017, 53, 6255-6258. [CrossRef]

20. Liao, J.; Wang, D.; Tang, A.; Fu, L.; Ouyang, J.; Yang, H. Surface modified halloysite nanotubes with different lumen diameters as drug carriers for cancer therapy. Chem. Commun. 2021, 57, 9470-9473. [CrossRef]

21. Rayner, J.H.; Brown, G. The Crystal Structure of Talc. Clays Clay Miner. 1973, 21, 103-114. [CrossRef]

22. Brigatti, M.; Galan, E.; Theng, B. Structures and mineralogy of clay minerals. Dev. Clay Sci. 2006, 1, 19-86. [CrossRef]

23. Claverie, M.; Dumas, A.; Careme, C.; Poirier, M.; Le Roux, C.; Micoud, P.; Martin, F.; Aymonier, C. Synthetic Talc and Talc-Like Structures: Preparation, Features and Applications. Chem. Eur. J. 2017, 24, 519-542. [CrossRef]

24. Dietemann, M.; Baillon, F.; Espitalier, F.; Calvet, R.; Greenhill-Hooper, M. Amorphous magnesium silicate ultrasound-assisted precipitation in a mixing system: Population balance modelling and crystallization rates identification. Powder Technol. 2019, 356, 83-96. [CrossRef]

25. Li, C.; Wang, R.; Lu, X.; Zhang, M. Mineralogical characteristics of unusual black talc ores in Guangfeng County, Jiangxi Province, China. Appl. Clay Sci. 2013, 74, 37-46. [CrossRef]

26. Andrić, L.; Terzić, A.; Aćimović-Pavlović, Z.; Pavlović, L.; Petrov, M. Comparative kinetic study of mechanical activation process of mica and talc for industrial application. Compos. Part B Eng. 2014, 59, 181-190. [CrossRef]

27. Fonseca, A.; Viana, M.; Querol, X.; Moreno, N.; de Francisco, I.; Estepa, C.; de la Fuente, G.F. Ultrafine and nanoparticle formation and emission mechanisms during laser processing of ceramic materials. J. Aerosol. Sci. 2015, 88, 48-57. [CrossRef]

28. Barcelos, I.D.; Cadore, A.R.; Alencar, A.B.; Maia, F.; Mania, E.; Oliveira, R.F.; Bufon, C.C.B.; Malachias, A.; Freitas, R.O.; Moreira, R.L.; et al. Infrared Fingerprints of Natural 2D Talc and Plasmon-Phonon Coupling in Graphene-Talc Heterostructures. ACS Photon. 2018, 5, 1912-1918. [CrossRef]

29. Wang, W.; Zhao, Y.; Yi, H.; Chen, T.; Kang, S.; Yunliang, Z.; Song, S. Preparation and characterization of self-assembly hydrogels with exfoliated montmorillonite nanosheets and chitosan. Nanotechnology 2018, 29, 025605. [CrossRef]

30. Yi, H.; Zhan, W.; Zhao, Y.; Qu, S.; Wang, W.; Chen, P.; Song, S. A novel core-shell structural montmorillonite nanosheets/stearic acid composite PCM for great promotion of thermal energy storage properties. Sol. Energy Mater. Sol. Cells 2019, 192, 57-64. [CrossRef]

31. Fan, M. Geological characteristics of Xitan black talc deposit in Guangfeng, Jiangxi province. Non-Met. Mines 1990, 4, 1-3.

32. Song, H. Study on ultrafine processing and application of calcined talc powder. China Non-Met. Min. Ind. 2001, 4, 19-22. [CrossRef]

33. Di, S.; Chen, Z. Guangfeng Pingtang Auriferous sedimentary black talc Mineralogical characteristics. Nonmet. Geol. 1993, 6, 11-14.

34. Tang, Q.; Gao, J.; Chen, X.; Zou, G.; Huang, B. Thermal decomposition behavior and influencing factors of Wansheng dolomite. Light Met. 2011, 3, 47-51.

35. Wu, X.; Zhao, H.; Zhang, Z.; Huang, C.; Min, X.; Fang, M.; Liu, Y. Study on phase behavior of talc at high temperature and properties of its composites. J. Ceram. 2017, 38, 476-480. [CrossRef]

36. Liu, X.; Liu, X.; Hu, Y. Investigation of the thermal decomposition of talc. Clays Clay Miner. 2014, 62, 137-144. [CrossRef]

37. Ohlberg, S.M.; Strickler, D.W. Determination of Percent Crystallinity of Partly Devitrified Glass by X-ray Diffraction. J. Am. Ceram. Soc. 1962, 45, 170-171. [CrossRef]

38. Aglietti, E.F.; Lopez, J.P. Physicochemical and thermal properties of mechanochemically activated talc. Mater. Res. Bull. 1992, 27, 1205-1216. [CrossRef]

39. Li, J.; Zuo, X.; Zhao, X.; Ouyang, J.; Yang, H. Insight into the effect of crystallographic structure on thermal conductivity of kaolinite nanoclay. Appl. Clay Sci. 2019, 173, 12-18. [CrossRef]

40. Zhang, M.; Hui, Q.; Lou, X.; Redfern, S.A.; Salje, E.K.; Tarantino, S.C. Dehydroxylation, proton migration, and structural changes in heated talc: An infrared spectroscopic study. Am. Miner. 2006, 91, 816-825. [CrossRef] 
41. Yang, H.; Qiu, G.; Wang, D. Structural changes of talc powder during superfine comminution. J. Chin. Ceram. Soc. 1999, 27, 5-13. [CrossRef]

42. Wang, C.; Liang, J.; Luo, J.; Liu, J.; Li, X.; Zhao, F.; Li, R.; Huang, H.; Zhao, S.; Zhang, L.; et al. A universal wet-chemistry synthesis of solid-state halide electrolytes for all-solid-state lithium-metal batteries. Sci. Adv. 2021, 7, eabh1896. [CrossRef]

43. Mote, V.; Purushotham, Y.; Dole, B. Williamson-Hall analysis in estimation of lattice strain in nanometer-sized ZnO particles. J. Theor. Appl. Phys. 2012, 6, 6. [CrossRef]

44. Petit, S.; Decarreau, A.; Martin, F.; Wiewiora, A.; De Parseval, P. Crystal-chemistry of talc: A near infrared (NIR) spectroscopy study. Am. Miner. 2004, 89, 319-326. [CrossRef]

45. Russell, J.D.; Farmer, V.C.; Velde, B. Replacement of OH by OD in layer silicates, and identification of the vibrations of these groups in infra-red spectra. Miner. Mag. 1970, 37, 869-879. [CrossRef]

46. Xie, W.; Wang, J.; Fu, L.; Tan, Q.; Tan, X.; Yang, H. Evolution of the crystallographic structure and physicochemical aspects of rectorite upon calcination. Appl. Clay Sci. 2020, 185, 105374. [CrossRef]

47. Lee, C.-K.; Tsay, C.-S. Surface Fractal Dimensions of Alumina and Aluminum Borate from Nitrogen Isotherms. J. Phys. Chem. B 1998, 102, 4123-4130. [CrossRef]

48. Liu, C.; Ma, T.; Li, Z.; Dai, S.; Guo, X.; Wang, Q.; Zhao, T. Progress in mechanochemical activation modification of natural minerals. Met. Mine 2021, 10, 75-81. [CrossRef]

49. Zhong, S.; Zhang, M.; Su, Q. Study on the mechanism of calcination of kaolin by microwave thermal method. J. Sun Yat-Sen Univ. 2005, 44, 71-74. [CrossRef]

50. Prajitno, M.Y.; Harbottle, D.; Hondow, N.; Zhang, H.; Hunter, T.N. The effect of pre-activation and milling on improving natural clinoptilolite for ion exchange of cesium and strontium. J. Environ. Chem. Eng. 2020, 8, 102991. [CrossRef]

51. Wang, C.; Hu, H.; Yan, S.; Zhang, Q. Activating $\mathrm{Bi}_{2} \mathrm{O}_{3}$ by ball milling to induce efficiently oxygen vacancy for incorporating iodide anions to form BiOI. Chem. Phys. 2020, 533, 110739. [CrossRef] 